\title{
Retrival Status of Paper and Pulp Mill Effluent Treated Fish Fed with Arthospira (Spirulina Platensis)
}

\author{
Dr. A. Arunachalam, ${ }^{1} *$ D. Thommai Arockia Gaspar, ${ }^{1}$ N. Muthamilarasi ${ }^{2}$ \\ ${ }^{1}$ Assistant Professor, Department of Zoology, Vivekanandha College of Arts and Sciences for Women \\ (Autonomous), Tiruchengode, Namakkal, India \\ ${ }^{2}$ M.Phil Scholar, Department of Zoology, Vivekanandha College of Arts and Sciences for Women \\ (Autonomous), Tiruchengode, Namakkal, India. \\ *thommaigaspar@gmail.com
}

\begin{abstract}
Spirulina is an aquatic algae in fresh water; it promotes the growth and biochemical compositions of the animals. Paper and pulp mill effluent affect the aquatic life of flora and fauna Oreochromis mossambicusis test animals in between the length of 5-10 cm were selected for the study.Test animal exposed to lethal concentration of effluent to the fish in 96 hours and various sub lethal concentrations were prepared as follows $0.5 \%, 1.0 \%, 1.5 \%, 2.0 \%$ and $2.5 \%$ in 30 days of duration. In the duration, the test animal was tested in the morphometric parameters such as weight, total length, standard length, head length, snout length and length of caudal peduncle and biochemical parameters such as amino acids, protein, carbohydrate, glucose and lipids; in between the interval of 10 days up to 30 days.Next the 30 days, the fishes are reared in the same sub lethal concentration with standard food and Spirulina feed. During these experimental days, the same biochemical constitutions were tested.In the experimental days, in first 30 days the biochemical values are reduced, and in the recovery period the reduced values were regained.
\end{abstract}

Keywords: Oreochromis mossambicus, Spirulina plantensis, Paper and pulp mill effluent, Biochemical compositions, Sublethal concentrations.

\section{INTRODUCTION}

Oreochromis mossambicus is one of the most successful largely cultured finfish species in the world, because of their fast growth rate and ability to feed low on the aquatic food chain. Moreover, tilapias are easy to reproduce and handling is having good resistance to disease and tolerance to wide range of environmental conditions. These are being found in over 100 countries (Balarin and Hatton, 1979). Fish meal, a major ingredient of fish feed, has to be imported, especially that with a protein content over $60 \%$. The high protein content of Spirulina is one of the main reasons for it being considered as a conventional source of protein. In addition, the amino acid pattern of the algae compares favorably with that of other food protein, its cells being capable of synthesizing all amino acids, thus providing all the essential ones to humans and animals (Spolaore, P. et al., 2006). Spirulina are multi cellular and filamentous blue-green algae that has gained considerable popularity in the health food industry and increasingly as a protein and vitamin supplement to aquaculture diets. It grows in water, can be harvested and processed easily and has very high macro and micro-nutrient contents (Habibet al., 2008). The paper and pulp industries discharged their insufficiently treated waste into the water resources, which makes serious problem to aquatic life of flora and fauna. Thus, it is necessary to develop an economical solution on the effluent discharged. Heavy metal accumulation in the aquatic environment could result in toxicity to both aquatic life and human. Edible fish present in aquatic bodies form an important group of organism as heavy metal once accumulated in fish tissues could act as a potential carrier of metal ion along the food chain. At the end, directly or indirectly the metal ion in the aquatic medium reaches to the man. Hence several studies involving bioaccumulation of heavy metals have been conducted in fishes found in river streams generally receiving industrial effluents containing toxic heavy metals and organic pollutants (Linton, et al, 2005).

\section{MATERIALS AND MeTHODS}

The common fresh water fish Oreochromis mossambicus (Mozambique Tilapia) was selected as animals. Oreochromis mossambicus fingerlings $(5-10 \mathrm{~cm})$ acquired from local pond, Namakkal 


\section{Dr. A. Arunachalam et al.}

district of Tamilnadu. They are maintained under laboratory condition for 60 days. During this period the water was changed regularly. The fish were feed daily in standard food and spirulina powder.

\subsection{Selection of Effluent}

The paper mill effluent collected from the local SPB paper mill industries Pallipalayam, Erode district of Tamil Nadu. Estimation of various physicochemical parameters of the effluent and the test water were carried out by following the method given by APHA (1980).

\subsection{Acute Toxicity Studies}

Acute toxicity tests were carried out using the effluent and the fishes to find out the $\mathrm{LC}_{50} / 96 \mathrm{hr}$ value of the effluent. Different effluent concentration namely 5\%, 10\%, 15\%, 20\% and 25\% were prepared.

\subsection{Biochemical Tests}

The biochemical parameters such as total protein, total amino acids, total glucose, total free sugars and total lipids were determined by Lowry's method, Desenting paper chromatography, Orthotoludine method, Phenol Sulphuric method respectively, from the tissue extract.

\section{RESULT}

\subsection{Morphometrical Analysis}

The morphometric characters of Oreochromis mossambicus were calculated to find a comparative study between the fish with effluent and fish with spirulina. Among 5 morphometric characters, parameters showed the values of mean and standard deviation they were weight 10.69 \pm 1.4 in (WE) and $12.39 \pm 1.27$ in (WS), total length $8.43 \pm 0.55$ in (WE) and $8.42 \pm 0.54$ in (WS), standard length $6.54 \pm 0.33$ in (WE) and $6.69 \pm 0.27$ in (WS), snout length $0.77 \pm 0.09$ in (WE) and $0.82 \pm 0.08$ in (WS), head length $2.36 \pm 0.20$ in (WE) and $2.37 \pm 0.21$ in (WS) and length of caudal peduncle $0.82 \pm 0.10$ in (WE) and $0.87 \pm 0.09$ in (WS).Thus, the increase of synchronized with the different degree of the increase to the above mentioned body parts. The morphometric differences between the populations may have appeared due to effluent and spirulina.

Table1. Comparative Morphometric Analysis of Oreochromis Mossambicus Feed with Spirulina (Each Value Is \pm SD of 6 Observations)

\begin{tabular}{|l|l|l|l|l|l|l|}
\hline \multirow{2}{*}{ Morphometric parameters } & \multicolumn{3}{|l|}{ Fish treated with effluent } & \multicolumn{3}{l|}{ Fish treated with spirulina } \\
\cline { 2 - 8 } & 10th day & 20th day & 30th day & 10th day & 20th day & 30th day \\
\hline weight $(\mathrm{g})$ & $6.48 \pm 1.67$ & $8.71 \pm 1.43$ & $10.69 \pm 1.4$ & $6.54 \pm 1.69$ & $9.22 \pm 1.56$ & $12.39 \pm 1.27$ \\
\hline Total length $(\mathrm{cm})$ & $7.09 \pm 0.7$ & $7.49 \pm 0.50$ & $8.43 \pm 0.55$ & $7.10 \pm 0.7$ & $7.61 \pm 0.46$ & $8.42 \pm 0.54$ \\
\hline Standard length $(\mathrm{cm})$ & $5.78 \pm 0.62$ & $6.13 \pm 0.59$ & $6.54 \pm 0.33$ & $5.81 \pm 0.6$ & $5.95 \pm 0.57$ & $6.69 \pm 0.27$ \\
\hline Snout length $(\mathrm{cm})$ & $0.73 \pm 0.11$ & $0.76 \pm 0.08$ & $0.77 \pm 0.09$ & $0.73 \pm 0.11$ & $0.80 \pm 0.08$ & $0.82 \pm 0.08$ \\
\hline Head length $(\mathrm{cm})$ & $2.0 \pm 0.18$ & $2.19 \pm 0.24$ & $2.36 \pm 0.20$ & $2.02 \pm 0.19$ & $2.27 \pm 0.14$ & $2.37 \pm 0.21$ \\
\hline Length of caudal peduncle $(\mathrm{cm})$ & $0.60 \pm 0.08$ & $0.77 \pm 0.07$ & $0.82 \pm 0.10$ & $0.60 \pm 0.08$ & $0.84 \pm 0.05$ & $0.87 \pm 0.09$ \\
\hline
\end{tabular}

\subsection{Acute Toxicity Studies}

The percentage of survival of Oreochromis mossambicus on exposed to different concentration of paper mill effluent is evident that $\mathrm{LC}_{50 /} / 96 \mathrm{hr}$ value was found to be $15 \%$ of the paper mill effluent.

\subsection{Biochemical Tests in Different Sub Lethal Concentrations}

The biochemical values of 30 days effluent treated fishes in different sub lethal concentrations are listed in Table.2. The values are gradually decreased and the same time after the 30 days in the same sub lethal concentrations fishes were fed with spirulina in next 30 days. During the period the biochemical values are gradually increased, it's also demonstrated in table.2.

Table2. Comparative Analysis of Biochemical Constituents in Effluent Treated Oreochromis Mossambicus and Fed with Spirulina for 30 Days.(Each Value is \pm SD Of 6 Observations)

\begin{tabular}{|c|c|c|c|c|c|c|c|c|c|c|}
\hline \multirow{2}{*}{$\begin{array}{l}\text { Effluent } \\
\text { Concentrati } \\
\text { on }\end{array}$} & \multicolumn{2}{|c|}{ Total proteins } & \multicolumn{2}{|c|}{ Total amino acids } & \multicolumn{2}{|c|}{ Total glucose } & \multicolumn{2}{|c|}{ otal free sugars } & \multicolumn{2}{|c|}{ Total lipids } \\
\hline & $*$ & $\mathrm{~S}$ & $*$ & $\mathrm{~S}$ & $*$ & S & $*$ & $\mathrm{~S}$ & $*$ & $\mathrm{~S}$ \\
\hline Control & $\begin{array}{l}26.78 \pm 1 . \\
96\end{array}$ & $\begin{array}{l}38.58 \pm 1 . \\
87\end{array}$ & $\begin{array}{l}14.89 \pm 1 . \\
54\end{array}$ & $\begin{array}{l}21.11 \pm 1 \\
13\end{array}$ & $\begin{array}{l}11.76 \pm 0 . \\
97\end{array}$ & $\begin{array}{l}15.27 \pm 1 \\
57\end{array}$ & $\begin{array}{l}37.18 \pm 2 . \\
43\end{array}$ & $\begin{array}{l}44.76 \pm 2 . \\
12\end{array}$ & $\begin{array}{l}8.19 \pm 0 . \\
76\end{array}$ & $\begin{array}{l}15.63 \pm 1 \\
67\end{array}$ \\
\hline $0.5 \%$ & $\begin{array}{l}19.38 \pm 1 . \\
63 \\
(-27.63)\end{array}$ & $\begin{array}{l}23.32 \pm 1 \\
53 \\
(+20.33)\end{array}$ & $\begin{array}{l}10.76 \pm 0 . \\
97 \\
(-27.06)\end{array}$ & $\begin{array}{l}12.96 \pm 0 . \\
75 \\
(+20.44)\end{array}$ & $\begin{array}{l}8.73 \pm 0.5 \\
3 \\
(-25.76)\end{array}$ & $\begin{array}{l}10.04 \pm 0 \\
73 \\
(+15.00)\end{array}$ & $\begin{array}{l}30.37 \pm 1 \\
73 \\
(-18.31)\end{array}$ & $\begin{array}{l}33.63 \pm 1 . \\
76 \\
(+10.73)\end{array}$ & $\begin{array}{l}5.11 \pm 0 . \\
16 \\
(-37.6)\end{array}$ & $\begin{array}{l}5.67 \pm 0.7 \\
3 \\
(+10.95)\end{array}$ \\
\hline $1.0 \%$ & $\begin{array}{l}19.11 \pm 1 \\
76\end{array}$ & $\begin{array}{l}22.55 \pm 1 \\
56\end{array}$ & $\begin{array}{l}10.58 \pm 0 . \\
76\end{array}$ & $\begin{array}{l}12.37 \pm 0 \\
81\end{array}$ & $\begin{array}{l}8.57 \pm 0.3 \\
9\end{array}$ & $\begin{array}{l}9.69 \pm 0.3 \\
8\end{array}$ & $\begin{array}{l}30.27 \pm 1 \\
44\end{array}$ & $\begin{array}{l}32.78 \pm 1 \\
27\end{array}$ & $\begin{array}{l}5.08 \pm 0 . \\
13\end{array}$ & $\begin{array}{l}5.63 \pm 0.7 \\
6\end{array}$ \\
\hline
\end{tabular}




\begin{tabular}{|c|c|c|c|c|c|c|c|c|c|c|}
\hline & $(-28.64)$ & $(+18.00)$ & $(-28.94)$ & $(+16.91)$ & $(-27.63)$ & $(+13.06)$ & $(-18.58)$ & $(+8.29)$ & $(-37.9)$ & $(+10.82)$ \\
\hline 1.5 & $\begin{array}{l}18.69 \pm 1 \\
57 \\
(-30.20)\end{array}$ & $\begin{array}{l}21.43 \pm 1 \\
38 \\
(+14.66)\end{array}$ & $\begin{array}{l}10.11 \pm 0 \\
38 \\
(-32.10)\end{array}$ & $\begin{array}{l}11.72 \pm 0 \\
18 \\
(+15.92)\end{array}$ & $\begin{array}{l}8.25 \pm 0.4 \\
5 \\
(-29.84)\end{array}$ & $\begin{array}{l}9.27 \pm 0.4 \\
9 \\
(+12.36)\end{array}$ & $\begin{array}{l}29.54 \pm 1 . \\
87 \\
(-20.76)\end{array}$ & $\begin{array}{l}31.57 \pm 1 \\
23 \\
(+6.87)\end{array}$ & $\begin{array}{l}4.99 \pm 0 . \\
27 \\
(-39.07)\end{array}$ & $\begin{array}{l}5.43 \pm 0.6 \\
3 \\
(+8.81)\end{array}$ \\
\hline 2.0 & $\begin{array}{l}18.15 \pm 1 \\
43 \\
(-32.22)\end{array}$ & $\begin{array}{l}19.98 \pm 1 \\
29 \\
(+10.08)\end{array}$ & $\begin{array}{l}9.56 \pm 0.8 \\
9 \\
(-35.79)\end{array}$ & $\begin{array}{l}10.82 \pm 0 . \\
33 \\
(+13.17)\end{array}$ & $\begin{array}{l}7.86 \pm 0.1 \\
3 \\
(-33.16)\end{array}$ & $\begin{array}{l}8.59 \pm 0.5 \\
5 \\
(+9.28)\end{array}$ & $\begin{array}{l}28.73 \pm 1 \\
28 \\
(-22.72)\end{array}$ & $\begin{array}{l}30.78 \pm 1 \\
71 \\
(+7.13)\end{array}$ & $\begin{array}{l}4.96 \pm 0 \\
32 \\
(-39.43)\end{array}$ & $\begin{array}{l}5.23 \pm 0.4 \\
5 \\
(+5.44)\end{array}$ \\
\hline $2.5 \%$ & $\begin{array}{l}16.84 \pm 1 \\
38 \\
(-37.11)\end{array}$ & $\begin{array}{l}18.58 \pm 1 \\
53 \\
(+10.33)\end{array}$ & $\begin{array}{l}8.97 \pm 0.7 \\
6 \\
(-39.75) \\
\end{array}$ & $\begin{array}{l}9.89 \pm 0.3 \\
5 \\
(+10.25)\end{array}$ & $\begin{array}{l}7.15 \pm 0.1 \\
6 \\
(-39.20) \\
\end{array}$ & $\begin{array}{l}7.75 \pm 0.7 \\
3 \\
(+8.39)\end{array}$ & $\begin{array}{l}26.98 \pm 1 \\
13 \\
(-27.43) \\
\end{array}$ & $\begin{array}{l}28.43 \pm 1 \\
35 \\
(+5.37)\end{array}$ & $\begin{array}{l}4.79 \pm 0 \\
76 \\
(-41.51)\end{array}$ & $\begin{array}{l}5.02 \pm 0.2 \\
7 \\
(+4.80)\end{array}$ \\
\hline
\end{tabular}

*-effluent treated fish, s-effluent treated fish with spirulina feed

\section{DisCuSSION}

In the present investigation resulted $50 \%$ of death in O.mosammbicus the $15 \%$ of concentration of paper and pulp mill effluent. Rajendra Kumar et al, (1991), reported the toxicity paper mill effluent to fish Puntiussophor, tests were conducted in two groups. In first group dilution were aerated. Where, as in group second dilutions were not aerated. LC50 for 96 hour was estimated at $1.5 \%$ whereas in second test it was recorded at $16.5 \%$. Varadaraj and Subramanian (1991), reported the toxicity of paper and pulp mill effluent to fingerlings of Oreochromis mossambicus and reported LC50 for 96 hrs. The 96 hrs LC50 value of paper and pulp mill effluent was 6\% respectively.

The reducing the growth rate of experimental fish in the Paper and pulp mill effluent, than the normal. Tyor, et al., (2012) reported that the paper mill effluent has the potential to cause developmental effects in fish. The paper milleffluent exposure induced abnormalities including conditions wherein, the yolk sac get protruded upto the head region, deformities in eyes, spinal curvature, abnormal head and overall stunted growthwere observed during the a study in Cyprinus carpio larvae.

In the present study indicates the reduce the biochemical concentration like proteins, amino acids, carbohydrates, total free sugars, lipids concentration of the fish when they exposed to the paper mill effluent. Parithabhanu.et al., (2014)reported thatan overall decrease in biochemical constituents like total proteins, total free sugars and total lipids in all the tissues like gill, liver and intestine due to the toxicity.

In the present study concluded that the paper and pulp mill effluent induces its effects on growth and biochemical alteration of the Oreochromis mossambicus. Gradually reduce the biochemical constituents of the test animal when exposure to the Paper and pulp mill effluent. However, during the retrival period,the depleted growth and tissue componentswere regained to certain extent which might bedue to the Spirulina feed. The spirulina promote the growth and biochemical components of the fish. The Spirulina to give the effluent treated fish, it regain the reduced values.

\section{ACKNOWLEDGEMENT}

Authors are thankful to the Principal, and other faculties for Department of Zoology, vivekanandha college of arts and sciences for women (Autonomous) for providing necessary laboratory facilities.

\section{REFERENCES}

Khan, N., Basheer, F., Singh, D. and Farooqi, I. (2011). Treatment of paper and pulp mill wastewater by column type sequencing batch reactor. Journal of Industrial Research Technology, 1(1),12-16.

Habib, M.A.B., Parvin, M., Huntington, T.C. and Hasan, M.R.(2008). A review on culture, production and use of Spirulina as food for humans and feeds for domestic animals and fish. FAO Fisheries and Aquaculture circular no 1034. Rome, FAO:41.

Linton, E.D., Scuton, D.A. and McKinley, R.S. (2005) Physiological effects of thermo mechanical newsprint mill effluent on Atlantic salmon (Salmosalar L.). Ecotoxicol. Environ. Saf. 62: 317330

Parvez, S. and Raisuddin, S. (2006). Copper modulates non-enzymatic antioxidants in the freshwater fish Channa punctata (Bloch) exposed to deltamethrin. Chemosphere, 62: 1324-1332.

Parithabhanu, A., Khusnumabegam, K.J. and Deepak.M. (2014).The influence of tannery effluent on biochemical Constituents in the tissues of oreochromis mossambicus. Int $j$ pharm bio sci; 5(1): (b) $920-924$. 
Dr. A. Arunachalam et al.

Rajendra Kumar, M., ChouhanSunita and K.D. Mishra,(1991). Toxicity of paper mill effluent to fish, Puntiussophor. J. Tissue Res., 1(1 and 2): 41-48.

Spolaore, P.,Joannis-Cassan, J., Duran, E. and Isambert, A.(2006).“Commercial applications of microalgae". J.Biosci. Bioeng. 101: 87-96.

Tyor, A.K., Fulia, A. and Sharma, R.K. (2012) Anomalies in Cyprinus carpio larvae exposed to paper mill effluent. $J$ of Biological Sciences, 12(5): 321-326.

Varadaraj, G. And M.A. Subramanian, (1991).Toxic effect of paper and pulp mill effluent on different parameters of bioenergetics in the fingerlings of Oreochromis mossambicus. Env. Eco., $9(4): 857-859$. 